ARTICLE

Received 28 Apr 2014 | Accepted 27 Nov 2014 | Published 20 Jan $2015 \quad$ DOI: 10.1057/palcomms.2014.5

\title{
Theatrical names and reference
}

\author{
Michael Y Bennett ${ }^{1}$
}

\begin{abstract}
The relationship between "character" and an "actor" appears to be quite straightforward: an actor acts as/plays character $[\mathrm{x}]$. But let us be more specific and reword this formulation: actor [y] acts as/plays Hamlet. Or - for the time of the play - actor [y] is Hamlet. And it is this last statement that is paradoxically utterly true and utterly false. It is in the name of a theatrical character that the tension between actor and character arises. Asking, for example, who is Hamlet? yields an answer where both actor and character have legitimate exclusive rights to being "Hamlet." In short, to whom/what does the name of a theatrical character refer? By first arguing that theatre works as a reverse-"beetle" languagegame, whereby I posit that theatre allows for private rule-making, I am able to turn to the idea of reference. It is by examining the name of theatrical characters and what these names refer to that I suggest that - following Hegel - theatrical names refer dialectically. Understanding theatrical characters as such, interpretation hinges not only on the output of theatre (i.e., the meaning), but also the input (i.e., the truth value).
\end{abstract}

\footnotetext{
${ }^{1}$ University of Wisconsin-Whitewater, 800 West Main Street, Whitewater, WI 53190, USA
} 


\section{Introduction}

... living beings more alive than those who breathe and wear clothes: beings less real perhaps, but truer! -Six Characters in Search of an Author

T he relationship between "character" and an "actor" appears to be quite straightforward: an actor acts as/plays character $[\mathrm{x}]$. But, let us be more specific and reword this formulation: actor [y] acts as/plays Hamlet. Or-for the time of the play-actor [y] is Hamlet. And it is this last statement that is paradoxically utterly true and utterly false. It is in the name of a theatrical character that the tension between actor and character arises. Asking, for example, who is Hamlet? yields an answer where both actor and character have legitimate exclusive rights to being "Hamlet". But this question also raises some significant ontological questions about reference and the existence of fictional entities. In short, to whom/what does the name of a theatrical character refer?

There have been, largely, three separate, but slightly overlapping "movements" within theatre studies that have employed/ been connected to philosophy: (1) studies in theatre semiotics in the late-1970s to early $1990 s^{1}$; (2) studies in the phenomenology of theatre from the mid-1980s to the early 2000s (see, especially, States, 1985; Garner, 1994; Rayner, 1994; Olf, 1997; McAuley, 2000; Carlson, 2003; Camp, 2004; Rayner, 2006; Osipovich, 2006; Roach, 2007); and (3) a rise in studies more interdisciplinary in nature starting in the early 2000s that rely on analytic philosophy and classic philosophy to read theatre and/or use theatre to study (most often) philosophical aesthetics.

Much of the most recent discourse surrounding theatre began in philosophical circles. In 2001, in a special symposium in The Journal of Aesthetics and Art Criticism, Saltz, James R Hamilton and Noel Carroll all discussed the relationship between text and performance in theatre. In short, Saltz and Carroll argue that an element of interpretation is needed to create performance (and, therefore, the text in some ways is the original that that is interpreted to make the performance, which is a once-removed artistic expression), while Hamilton suggests that performance is a unique art form. John Dilworth, in American Philosophical Quarterly and The Journal of Aesthetics and Art Criticism, has suggested that the notion of representation helps explain the nature of both dramatic text and theatrical performance, where a play is a type and performance is a token of that type (Dilworth, 2002a, b).

These debates set the stage for the groundbreaking 2006 collection, Staging Philosophy, edited by David Krasner and Saltz, whose essays explore a wide range of topics examining the intersection between philosophy and the theatre. This collection, in turn, paved the way for five monographs exploring this same intersection of theatre and philosophy. Hamilton's (2007) The Art of Theater is a further-developed book of the above-mentioned essay that is rooted in analytic philosophy and makes an argument that theatrical productions are not re-productions of a dramatic text, but are their own art form. Paul Woodruffs (2008) The Necessity of Theater is a philosophical meditation on how to make (good or bad) judgments about theatre, connecting these judgments to a larger question of ethics. Rokem's (2010) Philosophers and Thespians explores specific, historical encounters between philosophers and those in the theatre arts. Martin Puchner's The Drama of Ideas (2010) argues that a case can be made that drama extends from Plato, rather than from Aristotle (as has been the traditional argument). And my book, Words, Space, and the Audience: The Theatrical Tension between Empiricism and Rationalism (Bennett, 2012) argues that to make meaning out of theatre, the epistemological tension between understanding a play empirically and understanding it rationally must be explored.

As these recent books demonstrate, the study of philosophy has become (appropriately so) the latest breakthrough in theatre studies. The study of fictional worlds and fictional entities (more generally pertaining to literature) has actually, though, been around for quite some time in philosophical circles. These scholarly conversations surrounding fiction in philosophy, which has seen a resurgence over the past 10-plus years, are needed to move the field of theatre forward, which in turn, will yield new insights in ontology and the philosophy of aesthetics.

Theatre semioticians from the 1970s to the early 1990s spent a good deal of time (in most cases, indirectly) thinking about philosophical reference by investigating how a theatrical name is a signifier that signifies some sign. In 1983, Carlson wrote specifically about characters names from a semiotics standpoint, his article appropriately entitled, "The semiotics of character names in the drama". Carlson's essay is, more centrally, a theatre history of the naming process of theatrical characters (though clearly from the angle of theatre semiotics). Carlson's (1983) conclusions about realistic drama are that the dramatist of theatrical realism, "must be closely aware of the naming codes operating in the society his drama seeks to mirror". Though not really addressing reference in relation to specifically theatrical names, Degani-Raz (2003), 20 years later, connects the study of reference (in both the analytic tradition and semiotics) to her thesis that theatre refers to a "possible world". In this essay, I argue that a theatrical name becomes less of a code to mirror a society, and more of a real entity in-and-of-itself, the name referring to, what I call, a dialectical-synecdochic object.

Though I do come to some of the same conclusions about theatrical names as Carlson and Degani-Raz, I, however, begin my approach to this question from a different place than the previously mentioned scholars. Wittgenstein's "beetle" languagegame in Philosophical Investigations suggest, in opposition of René Descartes, that based on the ambiguity of a referent (for example, "beetle"), there is no such thing as a private language, but language and reality fall solely in the public realm. In this essay, by first arguing that theatre works as a "reverse-beetle" language-game, whereby I posit that theatre allows for private rule-making, I am able to turn to the idea of reference.

While Kripke's 1972 book Naming and Necessity may have sparked the interest and highlighted the importance that the study of referential names had/has to the field of philosophy, philosophers split into (according to Amie L Thomasson's important 1999 book, Fiction and Metaphysics) five camps surrounding the idea of whether and how a fictional entity, such as a character in a novel or a play, exists, some of these camps drawing on some of the foundational arguments of twentiethcentury analytic philosophy. Thomasson posits the following five groups: Meinongians ${ }^{2}$; Possibilists ${ }^{3}$; those who see fictional characters as objects of reference ${ }^{4}$; those who see fictional characters as imaginary objects ${ }^{5}$; and, finally (following her theory), Artifactualists. ${ }^{6}$ Following Berto (2011), it is also possible (and simpler) to categorize these groups as Meinongians (that is, fictional names refer to non-existent objects), Realists (that is, fictional names refer to-general-abstract objects) ${ }^{7}$ and Fictionalists (that is, fictional names do not refer). The philosophical study of fictional characters also possesses an inherent overlap with one of the fundamental subjects of analytic thought: the study of reference. And it is, at base, the study of reference that connects these five groups. Frege's pioneering work on sense and reference was taken up by Russell, whose seminal essay, "On Denoting", was a response to Meinong, who theorized the (non)existence of imaginary entities. And, thus, the study of literary characters combines the study of ontology following Quine (that is, What is there? or what exists?) with the study of reference (that is, What does a name, or what does a word refer to?).

While the study of literary characters has begun to take hold in certain circles in philosophy, and while the character, Hamlet, is 
used as an example by many of these relevant philosophers, in general, philosophers speak of Hamlet much like other fictional characters, such as Sherlock Holmes and Harry Potter. The key, and the missing detail, is that Hamlet is a theatrical character, and, while he exists, let us say, in a book, Hamlet also has a dual existence in that he exists on stage, too. And while philosophers have made great strides by studying literary characters, they have more-or-less overlooked the unique case that theatrical characters presents to the study of reference and ontology (among other things in analytic philosophy). It is by examining the name of theatrical characters and what these names refer to that I suggest that-following Hegel-theatrical names refer dialectically.

I argue that the name of a theatrical character refers to a dialectical-synecdochic object, as at least the "individual" exists in (at least) two manifestations. From here, I can posit an ambitious philosophical claim: that fictional entities fall into the same class of objects as words, which I call dialectical-synecdochic objects. From the theatre side, understanding theatrical names (and their characters) as such, ultimately, yields original observations about the roles (and responsibilities) of the actor. In short, my arguments suggest that theatrical interpretation (broadly conceived) should not just focus on meaning (that is, the output of a play), but also examine the necessary truths about a character and/or play (that is, the input and truth value of the play).

\section{Theatre as a "reverse-beetle" language-game}

To move forward, we must move back to the "movement" started just before what is widely considered the most important twentiethcentury book of philosophy: Wittgenstein's Philosophical Investigations. Wittgenstein's book was written as a refutation of (mostly) his own earlier work, Tractatus Logico-Philosophicus (1921), which inspired (along with the work of Russell) the logical positivists to make the study of language into a science, contemplating ideal notions of language. Wittgenstein's Philosophical Investigations was written over the course of the 1940s and published posthumously in 1953. He proposed that philosophy study how language is actually used (which, in turn, paved the way for the study of ordinary language philosophy). But in doing so, Wittgenstein's study of ordinary language posed a serious threat to Descartes. Decartes' pronouncement, cogito ergo sum, began "modern" philosophy and much of philosophy up until Wittgenstein either supported Descartes' rational enterprise, refuted it through empiricism or tried to balance the rational and the empirical.

First, to be clear, what does Decartes mean by cogito ergo sum? Descartes believed that knowledge about or gathered by his body was fallible (by human error, the demon or mixing it up with dreaming). However, for Descartes, the one thing that was beyond question was the fact that he was thinking. And, therefore, the fact that he thought (cogito) proved (ergo) his existence (sum). This thinking, through a private language, ${ }^{8}$ could only prove to Descartes his own existence.

What did Wittgenstein suggest? Wittgenstein created a thought experiment (one of many that) he called a "language-game" (something anyone can join). Suppose a number of people are given boxes that they were told contained a "beetle". However, each box does not contain a "beetle", but different objects. Nobody can see what is in each other's box. Given that the word "beetle" does not, then, refer to the same reality (Wittgenstein, 1969). In fact, the reality of the "beetle" does not even matter. We can conclude that therefore private language is impossible and the only reality is the public realm.

The wider implication here is about rule-following. Kripke, in Wittgenstein on Rules and Private Language, recaps Wittgenstein's sceptical argument about private language, connecting it to rulefollowing:
There can be no such thing as meaning anything by any word. Each new application we make is a leap in the dark; any present intention could be interpreted so as to accord with anything we may choose to do. So there can be neither accord, nor conflict. (Kripke, 1982: 55) ${ }^{9}$

Wittgenstein and Kripke may suggest, based on the above problems inherent in rule-following, that there is no "superlative fact" that can ever be attached to a word (Kripke, 1982: 69). Pettit, however, uses the example of the colour "red" and the biconditional statement- " $x$ is red if and only if it looks red to normal observers in normal conditions"-to help give a "conceptual explanation or genealogy" of rule-following:

People have red sensations-things look red to them-as a matter of primitive experience. Given those sensations, they find postboxes, ripe tomatoes, and heated metals similar in a salient respect. This enables them to use such examples then to indicate a certain property, namely the common colour. What colour? All they can say is, that colour, pointing at relevant examples. The colour is ostensively fixed for them. Well to a certain extent anyhow. It turns out that sometimes a ripe tomato looks different by their lights-and, no doubt, oursfrom how it does at other times, and indeed that it looks different as between different people. This offends against a supposition that its colour is fixed ... We are led toward the circular biconditional for redness: $\mathrm{x}$ is red if and only if it looks red to normal observers in normal conditions. The biconditional is worth marking, despite its circularity, because it encapsulates the account just sketched-an explanation or genealogy-of how people get the concept of redness going. (Pettit, 1990)

Kripke's (notion of) Wittengenstein suggests that there are three conditions in a community pertaining to rule-following: agreement, form of life and criteria (Kripke, 1982: 96-99). In Pettit's above example, there is agreement on the colour "red" by "normal observers in normal conditions". It is also an accepted form of life to call both a "ripe tomato" in a dark light and a brighter light "red" even though the shade and hue may appear different (and different to different people). And by "normal observers in normal conditions", this criterion of redness can be checked.

What, however, are the rules of theatre (or making meaning in the theatre)? I suggest, in the theatre in general, (character) A intends (character) $\mathrm{B}$ to understand $p$, but the audience (in addition to understanding the exchange of $p$ ) also understands an open-ended $q .{ }^{10}$ Theatre is clearly a shared form of life in that it is an accepted form of behaviour for people to gather together in a theatre and make up an audience, sitting in front of actors who are make-believing they are characters (in fourth-wall realism) who live out their lives unaware that they are in front of group of spectators. ${ }^{11}$ However, the problem with rule-following in the theatre is twofold. First, there is no agreement made on how to interpret: just agreement on the fact that interpretation is needed. In the theatre, there are also no accepted criteria- "circumstances, observable in the behavior of an individual, which, when present, would lead others to agree with his avowals ... [where] each person who claims to be following a rule can be checked by others" (Kripke, 1982: 100). If A avows that Hamlet is "mad", then should there be agreement in how to interpret, B should-following the agreement about interpretationalso be able to observe the criteria that has led A to avow Hamlet's "madness". Obviously, though, this subject of Hamlet's madness or sanity is hotly contested.

The only convention in literature, and especially theatre, especially after Gadamer's Truth and Method, is that the reader/ audience member, I argue, interprets the meaning from the reality 
in front of them. And there is no agreed-upon rule for determining what someone else says in literature or a play. On the contrary, interpretation is a private rule-making endeavour. The "beetle" language-game suggests interpretation by social convention. Theatre, rather, suggests interpretation by private convention or, even, private un- or non-conventional rules. While there are clearly well-known "techniques" of interpretation, these techniques (for example, "close reading") rarely yield the same results (with one common exception being if I choose to "read" a "text" through a specific theoretical lens [for example, postmodernism, feminism, queer theory, Marxism and so on], but, of course, I make the rule [outside of a school assignment] of whether or not I "read" a play through one of these theoretical lenses). In the "reverse-beetle" language-game (that is, theatre), there are no agreed-upon rules even to follow. Therefore, my interpretation depends on the rules that I either choose to follow or create. Where I depart from what Wittgenstein suggests is that while they focus on ordinary language, they go along with the assumption that there is potentially a particular rule to follow. What theatre, especially, presents to the philosopher of language, is that no such (particular) rule exists; in the moment of theatre, the only rules that generate meanings that I, myself, comprehend are the rules that I create and ultimately follow. Theatre offers a special case where some form of private language, private interpretation or (maybe most appropriately worded) private rule-making appears to exist.

In Wittgenstein on Rules and Private Language, Kripke concludes his book by explaining Wittgenstein's sceptical attack on the private language argument:

When I say, "I am in pain", I do not mean to draw the attention of others to a person identified in any particular way (e.g., identified as "the one who is standing in the corner"), but I draw attention to myself in the same way that if I groan I draw attention to myself. Thus others, hearing the groan, will say "Jones is in pain", "the person in the corner is in pain", and the like, if I am Jones, or the person in the corner. But I do not identify myself in this way; I may not even know whether I am Jones or the person in the corner, and, if I do my knowledge is irrelevant to my utterance. Thus the first person pronoun, for Wittgenstein, is to be assimilated neither to a name nor to a definite description referring to any particular person or other entity. (Kripke, 1982: 144-145)

However, Wittgenstein's language-game of the "beetle" and his discussion of "pain" are about shared experiences. But if after watching the same performance (which is a shared experience), A says, "I think Hamlet is mad", and B says, "I think Hamlet is a good actor", C would say, "A thinks Hamlet is mad and B thinks Hamlet is a good actor". While A and B may not think of themselves as "A" or "B" during their utterances, A and B will each identify their own thoughts and more important to private rule-making, their own thought processes, with their own mind. Thus, it is not the "thought" itself that suggests some form of private language, but the processes of thinking. In theatre, the response the audience should have is not specified: only that the audience should have a response. ${ }^{12}$ Thus, theatre is the ultimate language-game. Anyone can play it for the price of admission and, like Wittgenstein's language-games, theatre demonstrates "the fact that the speaking of language is part of an activity, or a form of life" (Wittgenstein \$23).

But why "play" it (that is, theatre)? Why create it? Because it is all about $M E$ (speaking for each individual)! Theatre provides an escape from language that is dictated by the speaker's intentions, which rules our lives; instead, I determine what YOU-the playwright, director, actors and so on-(are intending to) say to me. Theatre offers, through the enjoyment of the creative process, control of language-something normally out of our grasp, something that normally and uncontrollably defines $M E$. Instead, $I$ am the creator of your intention and meaning (and, thus, I am the creator of our shared reality); therefore, I do not just exist in the public realm (and neither does, say, C or D, who created your language differently than I created your language). Hence, we have a "reverse-beetle" language-game with very different rules from the one that Wittgenstein created: this language-game-that is, theatre-is the equivalent of a game where we all look into the same box, but are not told what the object is (though, it is a "beetle"); instructed to describe what is seen, instead, everyone gets to name and/or define the object in the box themselves (that is, describe the same reality in front of them in the box). ${ }^{13}$ Theatre, then, is a powerful case study on rule-following where all of the rule's applications cannot be known in advance, simply because, rather, the rules are unspecified and/or absent.

\section{From rule-following to reference}

Wittgenstein uses the notion of reference in his "beetle" languagegame to get to a discussion of private language and rule-following. I am using theatre as a case study as a specific counter-example to Wittgenstein's points on private language and rule-following, rather to get to a discussion of reference. The point that I am making and will continue to develop further in this essay is that if theatre is a (maybe, special) case where private rule-making occurs because interpretation happen via private thought processes, then it follows that there is a resulting difficulty in forming public agreement surrounding the referents in a play. This is significant because (1) from a philosophical standpoint, it raises key issues concerning the ontological status of fictional entities, and (2) from a theatrical standpoint, it allows for a new line of enquiry into interpreting (broadly conceived) a play, focusing also on truth, rather than just on meaning.

The study of reference in the philosophy of language begins with Frege (1960), ${ }^{14}$ who first notes that a sentence has a sense (that is, the thought expressed) and a reference (that is, what the word denotes, in a sense). Russell (1905), then, discusses definite descriptions and how a denoting phrase denotes one and only one entity (and if the definite description does not refer to an entity, then the sentence is false). Strawson (1950), later, suggests that the reference is not inherent in an expression (contra Russell), but referring is what someone uses an expression to do. And Donnellan notes that definite descriptions can have two types of uses: referential and attributive. Donnellan (1966) argues that a referential use of a definite description refers to a known entity, whereas an attributive use of a definite description refers to an unknown or uncertain entity.

In Russell's essay, “On Denoting”, which was largely a response to Meinong, Russell famously uses the phrase "The present king of France is bald" to argue (because there was no present king of France at the time Russell wrote his essay) that the sentence is false contra Meinong's earlier assertion that statements, even when statements are false, can still subsist in the human mind (see Russell, 1905: 490; Meinong, 1904; Meinong, 1981). Theatre provides Meinong's subsistence of fiction with an embodied reality to theorize: therefore, if the present bald king of France is put on stage, can we say that the present bald king of France exists? If so, how does he exist? Or maybe more importantly, what do the names of theatrical characters refer to?

Much of philosophical discussion surrounding reference in the mid-twentieth century had to do with truth conditions. That is, were particular sentences and/or statements true or false? J L Austin's "performative" eschewed the true/false binary, suggesting that there are statements, which Austin calls "performatives", 
which are neither true nor false. But the study over reference and truth was not over. In the expanding field of modal logic, the study of the counterfactual_if it were_t then __created fertile ground for studying much more complicated statements. Here, the advent of the study of "possible worlds" reinvigorated the study of reference. The counterfactual, in a sense, demanded the theory of "possible worlds" because the counterfactual conditions could be, or could have been, true if occurring in a different situation, or, rather, different world.

The study of modality is a branch of philosophical logic that examines truth conditions and expressions that qualify whether something is true or may be true (that is, necessity or possibility). While not the first (as Leibniz alluded to the idea and Kripke (re) introduced its study in the twentieth century), one of the foremost philosophers in the field of modal logic is Lewis, who has a notable and sustained body of work specifically on counterfactuals and "possible worlds". A counterfactual is a conditional statement that takes the form of the subjunctive: if [it] were..., then ... (that is, "if it were the case that _, then it would be that case that ..."; Lewis, 1976) stemming from Lewis' idea that "A counterfactual (or 'subjunctive') conditional is an invitation to consider what goes on in a selected 'counterfactual situation'; which is to say, at some other possible world" (Lewis, 1987). What are "possible world"? Lewis explains, "There are ever so many ways that a world might be; and one of these many ways is the way that this world is" (Ibid.: 2). A "possible world", then, is one "[way] that a world might be". However, there are also practically infinite "possible worlds": "There are so many other worlds, in fact, that absolutely every way that a world could possibly be is a way that some world is" (Ibid.). To be clear, a "possible world" has no utopian implications. Lewis is not necessarily contrasting our world to a possible world, either. Lewis' purpose does not have ethical implications, but is a tool to explore truth conditions: that is, whether a statement (particularly a counterfactual) is true, false or possibly true.

In this, Lewis complicates the matter of the counterfactual condition by stating that in order for a counterfactual condition to be necessarily true, it must be true in all possible worlds. That is, in order for something to be necessarily true, it must be true in every possible scenario that could (have) materialize(d) in the world. Why study possible worlds? Lewis provides a clear (almost humanistic) rationale: " $\ldots$ it is only by bringing the other worlds into the story that we can say in any concise way what character it takes to make what counterfactual true. The other worlds provide a frame of reference whereby we can characterize our world" (Ibid.: 22).

Kripke, in Naming and Necessity (among many other things), discusses modal logic and truth conditions across "possible worlds". In short, a contingent truth is one that exists in one or more "possible worlds", but not necessarily in every "possible world" (including our actual world). Kripke creates the term, "rigid designator", for a name that necessarily refers to the same object or individual object in all possible worlds.

\section{Theatrical names and reference: dialectical-synecdochic objects}

The study of fictional characters (also called fictional entities) has been found to have quite broad implications for analytic philosophy. Following his 1972 seminal book, Naming and Necessity - which explore what names refer to in relation to conversations in modal logic and the study of reference-in his 2011 essay, "Vacuous Names and Fictional Entities", Kripke discusses fictional characters by way of pretence. Kripke (2011) asserts that fiction, "is a pretense that what is happening in the story is really going on". Given this, Kripke (2011:59) argues that while a fictional character does not have an actual referent (and, thus, his or her name is vacuous), that "it is pretended to have a referent". Furthermore, "The propositions that occur in the story, then, are not genuine propositions saying something about some particular person; they are instead merely pretended propositions" (Ibid.). Kripke says that fictional characters are not possible characters, but real people in a pretend world.

Stone, in opposition to Kripke, writes about existence and fictional characters in relation to the imprecision of descriptions (using Harry Potter as an example):

Descriptions can be imprecise because they are vague, but sometimes they are imprecise because they are incomplete. (The criminal I saw had one head, two arms and two legs, I tell the police.) Those who believe Harry Potter is a possible person are faced with two related difficulties that flow from the story's imprecision. First, the singular term "Harry Potter" fails to refer to a possible person in our statements about Rowling's hero, since many possible boys have an equal claim to be its referent. Second, as no possible boy is the referent of "Harry Potter", no possible boy, if he had existed, would have been Harry Potter ... The referent of a fictional proper name, under any suitable precisification, is a possible object. "Harry Potter might have existed" is true on this account, and the two difficulties can be met. "Harry Potter" denotes just one possible boy who, if he had existed, would have been Harry Potter. (Stone, 2010)

Stone's argument about the description of possible worlds is about literary fiction (that is, in this case, a series of seven novels). In theatre, as I argue, the names of characters refer "two" individuals in "two" (different) "possible worlds" (that is, the one in the text and the one or, rather, many, almost infinite) on stage. What I explore is the contradiction present between these "two", if you will, existences referred to by the name of a theatrical character.

Keeping in mind the "actor", let us think about the character that the actor is playing. We tend to talk about Hamlet, for example, in two ways: the Hamlet in Shakespeare's text and, say, Actor X's Hamlet or Actor Y's Hamlet. Clearly, the text always refers to the same Hamlet, right? The question that begs investigation is what does the name, "Hamlet", refer to? In other words, does the name of a theatrical character always refer to (and mean) the same thing? ${ }^{15}$

"Hamlet" names the character that is described by what he says and does in the text. "Hamlet" is identical with the sum total of the lines and actions in the play: in other words, "Hamlet" = Hamlet's acts (keeping with the idea that his utterances are also acts). In the text, the name "Hamlet" directly refers analytically, because, by definition, Hamlet, necessarily, is the sum total of his acts in the play.

But what about the actor? Can anyone say that Actor X's Hamlet and Actor Y's Hamlet are the same character? Is Hamlet the same character in portrayals by Burbage, Betterton, Bernhardt, Olivier, Branagh and Gibson? No. It generally takes watching $5 \mathrm{~min}$ to determine that these Hamlets are different. However, and this is vitally important, it also could be true that they are the same character. (For example, the identical twins, Mary Kate Olson and Ashley Olson, both played "Michelle" on Full House, and who could say that Michelle was two different characters in that show? And how many people, especially the children watching the show, even realized or knew that Michelle was played by two different actors?) Therefore, on stage, Hamlet exists as a contingent a posteriori truth. We come to this conclusion that we cannot say that on stage "Hamlet" = Hamlet: for when multiple actors have played Hamlet, the name "Hamlet" 
rarely directly refers to the same character, but given that Hamlet could be acted the same way by two different actors (and therefore it can be true contingently), we can only verify which case it is (that is, the same or different Hamlet) through a posteriori knowledge (that is, watching the two performances). Importantly, then, the name "Hamlet" on stage refers synthetically (because the acts can only be described as an a posteriori contingency), which differs from (as already discussed) the "Hamlet" in the text, which refers analytically.

To negotiate this contradiction, what if we turn, instead, to Hegel? I argue that the name of a theatrical character refers dialectically (as opposed to directly referring or indirectly referring). Contrary to most notions in literary criticism that suggest that the dialectical process is the synthesis of a thesis and antithesis, Hegel's dialectical process is a three-step process whereby the subject (1) begins with an abstract notion (of an object or thing), then (2) views the "determinate" (object or thing) and then finally (3) resolves the abstract and determinate to embody something truer (about the object or thing) than either the abstract notion or the "determinate". Applying the Hegelian dialectic to understanding what the name of a theatrical character refers to, the audience member has an abstract notion of Hamlet, let us say, and then, after contrasting the "determinate" Hamlet, comes to understand Hamlet in the truest light. This, so importantly, highlights the individuating process of interpretation. This is how the name "Hamlet" refers to and means different things to different people and also how Hamlet actually exists as different individuals. This individuation of interpretation is possible because the abstract notion of Hamlet is not the same for everyone, nor is, as pointed out about the theatre, the viewing experience the same for everyone (and that is assuming everyone has seen the same and only the same productions of Hamlet, which of course is not the case).

To be very clear, I am not about to suggest that there is no such thing as Kripke's "rigid designator", or that a "rigid designator" refers to more than (only) one referent. I argue, rather, that reference and meaning do not necessarily align for "rigid designators". I take the case of rigid designation because this observation probably does not need to be made about non-rigid designators (that is, that the reference and meaning do not line up). My purpose is to describe the manner in which the intersection/overlap between reference and meaning makes communication possible (or its lack makes miscommunication possible). Rigid versus non-rigid designators are specific terms for the study of reference. Here, given that I am discussing theatrical characters, I am concerned with reference and meaning; thus, "dialectical designators" do not replace rigid and/or non-rigid designators, but are a different type of term meant to show that the convergence or non-convergence between reference and meaning is the same for both rigid designators and non-rigid designators: that rigid designators do not occupy a special class of words where reference and meaning necessarily are the same.

This critical move allows me to suggest that since no words (again, even rigid designators) have a one-to-one correspondence between reference and meaning, that there is an inherent act of (metaphorical) interpretation needed for communication. This suggests, further, how, or in what way, words exist. To put forth a new hypothesis regarding the ontological status of fictional entities, it is first necessary to understand how words exist, as (at least) fictional entities and fictional worlds exist (or do not exist) through words. The (seemingly direct) case of the proper noun/ "rigid designator" demonstrates (rather) a perceived gap in our understanding of words. In short, if you never heard of me, never met me and never saw a picture of me, would your "Michael Y Bennett" refer in the same manner, and mean the same thing, as say, to my mother, or to my wife?
Herein lies the dual problem: experience and performances of the self. Given that I interact contextually, performing myself (in a sense) differently given who I am around and the social context, I am not the same person to you, to my mother, to my wife or even to myself. ${ }^{16}$ So because of the differences in levels of experience and how one encounters my performances of myself, the referent "Michael Y Bennett" will mean something along the spectrum of "Michael Y Bennett" as-to borrow Hegel's terminology-an "abstract" concept and "Michael Y Bennett" as a "determinate" object (ultimately "synthesized" into one's own individualized "Michael Y Bennett" via Hegel). While the "abstract-Michael Y Bennett" and the "determinate-Michael Y Bennett" do, indeed, refer rigidly to the same "referent", how come "Michael Y Bennett" does not yield the same meaning (that is, the same understanding of the referent)? That is why I propose that all proper nouns are, what I call, dialectical designators.

While Hegel was not directly concerned with questions of reference, in a sense, Hegel's dialectics can be very well applied to the study of reference. In short, the abstract notion of an object or thing for Hegel is more-or-less the intension of an object or thing (that is, more-or-less its dictionary definition), while the "determinate" is an extension of the object or thing (that is, a realworld example or case). Therefore, a cat's intensional meaning is something like, a domesticated feline that is frequent a pet, while a cat's extensional meaning are individual cats, that is, Cat1, Cat 2, Cat3, ... (that is, specific cats, such as, Fluffy, Belle, Mellow and so on). To Hegel, the abstract-intensional notion is not the truest sense of a "cat", nor are the determinate-extentional examples (for example, Cat1, Fluffy, Cat $3, \ldots$ ). It is by resolving the abstract-intensional notion with the determinate-extensional example that one will have a truer sense of, for example, a "cat".

Language, given its inherent level of ambiguity/vagueness, essentially functions via interpretation. Derived from the "cluster" of (denoted and connoted) "subjects" and/or "predicates" inherent in the literal definition(s) of the word, interpretation hinges on, I argue, the a particular selection of concepts from a word that functions as, what I call a dialectical designator. That is, language is inherently "ambiguous" (or "vague") precisely because an individual may draw upon and select any number of "subjects" and/or "predicates" that make up the definition(s) of a wordwhat I refer to as the "literal-synecdochic elements" of a word. This phrase (that is, "literal-synecdochic elements") is both selfexplanatory (in that the conceptual parts of/elements within a definition are both "literal" and can function "synecdochically"), but also needs a bit of further explanation. The idea here is that a word is a collection of separate intensional terms/concepts that, all together, form the meaning of the word. However, in metaphor, these intensional terms and concepts can be created through synecdoche, but also through unique combinations of these synecdochic-intensional terms (which is another possible way to say, "literal-synecdochic elements").

Upon further selection, the individual also "synthesizes" (in a dialectical manner) each of these "subjects"/"predicates" located somewhere on the spectrum between the "determinate" and the "abstract" notion of the "subjects", "predicates" and the word, itself. In short, interpretation, and thus, communication, relies on a particular combination of each word's literal-synecdochic elements. Communication, then, is successful when there exists enough of an overlap and/or convergence between the literalsynecdochic elements in language created by the speaker and interpreted by the receiver of that utterance; if there is not enough of an overlap and/or convergence, then the possibilities for miscommunication arise. ${ }^{17}$

I argue that words are dialectical designators, or dialecticalsynecdochic objects, because an individual interpreter (either utterer or receiver of the utterance) selects a particular set of 
abstract-intensional terms in each word and, also, synthesizes these intensional terms with a particular set of determinateextensional terms, to yield an individualized meaning of a word. Again, when there is sufficient overlap and/or convergence between the terms uttered by a speaker and understood by the receiver of that utterance, then communication is successful; if not, then miscommunication may arise. ${ }^{18}$

Fiction (broadly defined, including theatre) works to communicate because, as discussed by Dohrn (2009), "Ordinary counterfactual thinking must remain intact as the basis of interpretive capacities. However, it is overridden by a sense of what is relevant to a piece of literature" (that is, what is relevant are the "paradigm scenarios" of fiction that "have been chosen for the narrative"). That is, humans approach fiction by just examining the local similarity of "possible worlds being nearby, being like the actual one in all respects in what they are not explicitly thought to be different" (Dohrn, 2009: 42).

Dialectical-synecdochic objects do not exist in the actual world, per se, or else they would be existent, actual objects (and, therefore, neither "fictional" nor "possible", but actual). But just as a unique collection of actual "subjects" and "predicates" (that is, literal-synecdochic elements) make up a word, so-toodo actual "subjects" and "predicates" (that is, again, literalsynecdochic elements) make up a fictional entity. That is, fictional entities are all just as real/actual as words, or, have the same ontological status as words.

But there is a major problem still to be resolved. Does the text or the performance contain the abstract-intensional notion of Hamlet? And which is the determinate-extensional notion? It is not so simple and Hegel's dialectics do not work exactly correctly in the case of a theatrical character. To try to help, we could change the language from abstract to universal and determinate to particular. Maybe the textual "Hamlet" is the universal Hamlet, while the staged "Hamlet" is a particular Hamlet. And thus the dialectical process combines the text with the performance to determine who is Hamlet to each person. But this language (that is, universal and particular) turns the name and the reference of the theatrical character into something trite and equally simple. And this covers up the complexities we just uncovered. Going back to the question of which is the abstract and which the determinate, a case can be argued either way, for the textual "Hamlet" refers to something only in the mind, without a physical reality (suggesting the abstract), but yet it refers analytically, by definition (suggesting something "determinate"), and the staged "Hamlet" refers to a physical reality (suggesting something "determinate"), but yet this synthetic reference is for a fleeting moment in time and many "Hamlet's" exist (suggesting the abstract).

I do not think, though, that the answer has to be solved: rather, it is the answer, in a sense. Just as there is a great divide between philosophers over the millennia in terms of viewing the world empirically or rationally, we can say that each audience member's personal propensity for weighing the abstract and the "determinate" affects who or what the character refers to for each individual from their differing dialectical processes. The audience member-whose dialectical process of determining who Hamlet is and what/whom "Hamlet" refers to-aids in the process, whereby the ontological boundaries of who Hamlet is expands with each audience member's reading and viewing of the play.

\section{On interpreting}

Two questions still remain: (1) What role does dialectical reference play in the theatre? and (2) How does our sense of dialectical references affect acts and acting? A definite description and a "rigid designator" (via Kripke's Naming and Necessity) refer to an entity in "all possible worlds". Using Russell and Kripke,
"Hamlet", then, would refer to the exact same entity in all "possible worlds". Given what I wrote above, it seems clear that "Hamlet" does not refer to exactly the same thing in all "possible worlds" (and hence "Hamlet" and other names of theatrical characters are dialectical references). However, can "Hamlet" refer to the same thing in all "possible worlds"? ${ }^{19}$ In other words, is there something common to the name "Hamlet" in all "possible worlds"-some necessarily true kernel of Hamlet? I think this is where the intersection of act, acting and actor come into play. The act (that is, all the textual acts), refers to the analytic, textual "Hamlet". But it depends on how the act is acted by the actor that determines the meaning of the act. The actor interprets how to act the act. And while "Hamlet" refers dialectically, the actor, I argue, has a major role when portraying Hamlet: the actor's interpretation (that is, the actor's view/portrayal/reading/acting of Hamlet) must-to explore the truth of the play, character and the world-contain the kernel of Hamlet that is true in all "possible worlds" (that is, in the case of theatre, all possible readings and productions of the play). That does not mean, however, that the name "Hamlet" only refers to the kernel of Hamlet that is true in all "possible worlds": Hamlet is, and can be, so much more.

Theatre, then, is an activity exploring truth, but it an everadaptable language-game that allows individuals to collaboratively explore truth in all "possible worlds". And this idea of a kernel of a theatrical character or a kernel of a play that exists in all possible worlds (that comes directly out of our exploration of theatre and the philosophy of language) presents a new way to think about both producing and interpreting a play. What-the director, actors, scholar and so on asks-is contingently true (that is, sometimes true and sometimes false) about a particular play or theatrical character? And what is necessarily true (that is, true in all possible worlds) about a particular play or theatrical character? ${ }^{20}$

These questions create a new line of enquiry for those associated with theatre. These two questions allow both the theatre practitioner and the scholar to approach the input of theatre (that is, its truth) versus the output of theatre (that is, its meaning). That is not to say, by any means, that the enterprise of meaning should be abandoned. On the contrary, the study of truth should serve as a building block to strengthen the enterprise of meaning.

\section{Notes}

1 See especially, Elaine Aston and George Savona, Theatre as Sign System: A Semiotics of Text and Performance; Carlson, Theatre Semiotics: Signs of Life; Keir Elam, The Semiotics of Theatre and Drama; Erika Fischer-Lichte, The Semiotics of Theater: Marco de Marinis, The Semiotics of Performance; Patrice Pavis, Languages of the Stage: Essays in the Semiology of Theatre.

2 Meinongians-most notably Parsons, Zalta and Rapaport-believe that fictional characters do not exist (that is, non-existent entities) or they are abstract (that is, abstract entities), but are located in an ontological realm that is now called, "Meinong's jungle". See Thomasson 14-17.

3 Possibilists-Kripke and Plantinga fall into this category (as do I, in the most general sense)-suggest that fictional characters are unactualized possibilia (that is, a member of a possible world, given that it would be plausible that a particular literary character could have existed, especially if the state of affairs in the world was different). See Thomasson 17-18.

4 Philosophers like Crittenden and van Inwagen posit that fictional characters are simply objects of reference within human discourse. See Thomasson 18-21.

5 Sartre suggests that fictional entities are imaginative acts, dependent on intentionality for their creation and sustaining them. See Thomasson 21-23.

6 Thomasson's notion of an artifactual theory relies on dependence. In short, Thomasson suggests that fictional entities are dependent objects, dependent to literary works and the act of creation by an author; much like other everyday objects that exist as abstract objects-dependent on spatiotemporal entities-and/or mentally dependent objects. See, especially, Thomasson 24-42, 146-153.

7 The realists, broadly speaking, include the possibilists, those who see fictional characters as objects of reference, those who see fictional characters as imaginary objects and the artifactualists. 
8 This notion of thinking through a private language comes via Wittgenstein's implied conception of Descartes.

9 However, also according to Wittgenstein, rules are "rails invisibly laid to infinity" (Wittgenstein \$218). This metaphor, along with Wittgenstein’s discussion of "intuition", has sparked a debate within scholarship about rule-following and whether or not Wittgenstein saw rule-following as predetermined and whether or not Wittgenstein was a realist or antirealist. To see a full explanation of the debate surrounding these two above issues, see Panjvani (2008) and his footnotes.

10 Husserl, Anscombe, Ayer and Dennett are lurking in the background for their work on intentionality, as are-even more so-ordinary language philosophers such as Searle, Strawson, Grice and Austin. For more, specifically, on the study of intention as it relates to the theatre, see Saltz (2000) and Goldman (1992). Though not specifically concerning intentionality, the idea is inherent in the study of theatre semiotics, which was most prominent in theatre/drama studies in the 1970s to early 1990s. See, for example, Elaine Aston and George Savona's, Theatre as Sign System: A Semiotics of Text and Performance; Carlson's, Theatre Semiotics: Signs of Life; Keir Elam's, The Semiotics of Theatre and Drama; Erika Fischer-Lichte's, The Semiotics of Theater; Marco de Marinis's, The Semiotics of Performance; and Patrice Pavis's, Languages of the Stage: Essays in the Semiology of Theatre. A few philosophies of aesthetics are also useful here. In Painting as Art, Richard Wollheim develops a theory of "seeing in" versus "seeing as". When one sees $\mathrm{x}$ as $\mathrm{y}$, one observes $\mathrm{x}$ and $\mathrm{y}$ in the same ontological category (for example, the painting of a horse as a horse). In a sense, "seeing as" is similar to what Nelson Goodman, in Languages of Art, suggests happens in pictures, where-like in language-representations refer (and have a corresponding grammar of syntactic and semantic rules). However, to return to Wollheim, in art (particularly painting), one may see $\mathrm{y}$ in $\mathrm{x}$ (for example, horror in an abstract painting, majesty in a painted cloud, a call for democratic ideals in a painting of farmworkers and so on). In this respect, Roger Scruton, in his book Art and Imagination, discusses how art has a "double intentionality", where an experience is both directed at the work of art and also what is taken away from it (Roger Scruton's explanation of his own work on aesthetics and the work of Wollheim and Goodman was invaluable [Scruton 351353]). Finally, an entire play, of course, just like an entire novel or a painting, is a metaphor in-and-of-itself. Discussing metaphor and interpretation, McGonigal turns to Crispin Wright's theories of metaphor to object to David Cooper's notions of metaphoric "indeterminacy" (with Cooper arguing against a speaker's meaning/ intention when it comes to metaphor) (see McGonigal, 2002: 179-190).

11 For more on the complex relationship between audience and theatrical event, see, among others, Philip Auslander's, Liveness; Michael Y Bennett's, Words, Space, and the Audience: The Theatrical Tension between Empiricism and Rationalism; Susan Bennett's, Theatre Audiences; Herbert Blau's, The Audience; and Dennis Kennedy's, The Spectator and the Spectacle.

12 Velleman (1997) discusses how groups of individuals can have a shared intention. Velleman explains in the example when a person utters, "I am going for a walk" that "An interesting feature of this arrangement is that I do not take discretion over your behavior, nor you over mine; rather, you give me conditional discretion over your behavior, and vice versa" (48). This is somewhat similar to what happens in the theatre, but the focus in the theatre is not on behaviour (though it does not encompass it, as the acts by the actors force an act of understanding and interpretation by the audience), but particularly on intention and meaning. The above equation would work in the theatre as we (that is, the playwright, director, actors and so on) give you conditional discretion of our intention and meaning.

13 Panjvani argues powerfully against an "explanatory-transcendent" understanding (using Crispin Wright's term) of rule-following, suggesting that any such understanding would contradict Wittgenstein's private language argument (303-328).

14 The following "history", if you will, of the study of reference in philosophy is, of course, utterly limited. See also Degani-Raz (2003: 307-329). Degani-Raz, as this is largely the stated purpose of her previously mentioned article, provides a wonderful and extremely in-depth history, though creating a somewhat different lineage, of the study of reference (both in the analytic and semiotic traditions).

15 Martí (2003) raised the possibility of directly referring non-rigid designators by suggesting that there is a conceptual relationship between rigidity and direct reference. For two articles that argue against Martís idea, and in favour of the widely accepted view that direct references must also be rigid designators, see Sullivan (2005) and Zouhar (2011).

16 I intend this idea of performances of the self to imply both Goffman's sense that humans are social actors (see Goffman, 1959), but also Sartre's notion of performing in "bad faith", and even the difficulty of performing in "good faith", given that one must be aware of what performing in "bad faith" is, and therefore, is performing, versus simply doing something, nonetheless (see Sartre, 1993).

17 What I do not address is how or why a particular concept is selected or not selected, as this is well beyond the scope of this chapter (and book). I will leave this line of enquiry to more qualified thinkers: philosophers of mind and those in the fields of psychology and the neurosciences.

18 The two games, charades and Taboo, provide no greater example of both communication and miscommunication based on the interpretation of the "literal-synecdochic elements" in words. An entire essay could be written analysing these two games using this theory of meaning.
19 Although this is beyond the scope of this essay, it should be noted that this is a particularly more difficult question when theatrical adaptations are thrown into the equation. Appropriations of Hamlet as a character in Tom Stoppard's Rosencrantz and Guildenstern are Dead and in Heiner Muller's Hamletmachine complicate the question of similarity and difference between "possible worlds".

20 While the subject of actor training and technique is entirely beyond of the scope of this present essay, these two questions can clearly form a new line of enquiry theorizing the training and technique of actors. An entire book exploring the connection of the input of theatre (that is, the truth value of a play) and the quest of the actor to find the truth of a scene, the truth of the play, the truth of themselves, and the truth of the character is a natural and logical extension of this present chapter. Further exploration into this above line of enquiry can give a solid intellectual and theoretical backing to help explain how an actor (can) sustain(s) an imaginary world, and raise the question, what "possible world" will I walk into today? Also, the two questions I raise are even more relevant for actor training and technique if thinking, particularly, about Stanislavsky's notions of abstracting, given the circumstances, and internalizing the text versus externalizing the text.

\section{References}

Bennett MY (2012) Words, Space, and the Audience: The Theatrical Tension between Empiricism and Rationalism. New York. Palgrave Macmillan.

Berto F (2011) Modal Meinongianism and fiction: The best of three worlds. Philosophical Studies; 152: 316-321.

Camp P (2004) The trouble with phenomenology. Journal of Dramatic Theory and Criticism; 19 (1): 79-100.

Carlson M (1983) The semiotics of character names in the drama. Semiotica; $44(3 / 4): 285$

Carlson M (2003) The haunted stage.

Degani-Raz I (2003) Possible worlds and the concept of "reference" in the semiotics of theater. Semiotica; 147 (1/4): 325-327.

Dilworth J (2002a) Theater, Representation, Types, and Interpretation. American Philosophical Quarterly; 39.2 (April): 197-209.

Dilworth J (2002b) The Fictionality of Plays. The Journal of Aesthetics and Art Criticism; 60.3 (Summer): 263-273.

Donnellan K (1966) Reference and definite descriptions. The Philosophical Review 75 (3): 281-304.

Dohrn D (2009) Counterfactual narrative explanation. The Journal of Aesthetics and Art Criticism; 67 (1): 42.

Frege G Über Sinn und Bedeutung. Zeitschrift für Philosophie und philosophische Kritik; 100: 25-50.

Frege G (1960) On sense and reference. Trans. Black M. In: Geach P and Black M (eds) Translations from the Philosophical Writings of Gottlob Frege, 2nd edn. Blackwell: Oxford, pp 56-78.

Garner Jr, S B (1994) Bodied Spaces: Phenomenology and Performance in Contemporary Drama.

Goffman E (1959) The Presentation of Self in Everyday Life. Anchor Books: New York Goldman M (1992) 'Hamlet': Entering the text. Theatre Journal; 44 (4): 449-460. Hamilton J (2007) The Art of Theater. Oxford. Blackwell.

Kripke S A (1982) Wittgenstein on Rules and Private Language. Harvard University Press: Cambridge, p 55.

Kripke S (2011) Vacuous names and fictional entities. In: Philosophical Troubles: Collected Papers, Volume 1. Oxford University Press: New York, p 58.

Lewis D K (1976) Counterfactuals. Harvard University Press: Cambridge, p 2.

Lewis D (1987) On the Plurality of Worlds. Basil Blackwell: Oxford, pp 20-21.

Martí G (2003) The Question of Rigidity in New Theories of Reference. Noûs; 37 (1): 161-179.

McAuley G (2000) Space in Performance.

McGonigal A (2002) Metaphor, indeterminacy, and intention. British Journal of Aesthetics; 42 (2): 179-190.

Meinong A (ed) (1904) Über Gegenstandstheorie. In: Untersuchung zur Gegenstandstheorie und Psychologie. J. A. Barth: Leipzig, pp 1-51.

Meinong A (1981) The theory of objects. Trans. Levi I, Terrell D B and Chisholm R. In: Chisholm R (ed) Realism and the Background of Phenomenology. Ridgeview: Atascadero, CA, pp 76-117.

Olf J (1997) Reading the dramatic text for production. Theatre Topics; 7 (2): 153-169.

Osipovich D (2006) What is theatrical performance? Journal of Aesthetics and Art Criticism; 64 (4): 461-470.

Panjvani C (2008) Rule-Following, Explanation-Transcendence, and Private Language. Mind; 117.466 (April): 311-315.

Pettit P (1990) Affirming the reality of rule-following. Mind; 99 (395): 435.

Rayner A (1994) To Act, To Do, To Perform.

Rayner A (2006) Ghosts.

Roach J (2007) It.

Rokem F (2010) Philosophers and Thespians: Thinking Performance. Stanford. Stanford University Press.

Russell B (1905) On denoting. Mind; 14 (56): 479-493.

Saltz D Z (2000) The reality of doing: Real speech acts in the theatre. In: Krasner D (ed) Method Acting Reconsidered: Theory, Practice, Future. St. Martin's: New York, pp 61-79. 
Sartre J-P (1993) Being and Nothingness. Trans. Hazel E B. Washington Square Press: New York, pp 86-118.

Scruton R (1996) Modern Philosophy: An Introduction and a Survey. Penguin, pp 351-353.

States B O (1985) Great Awakenings in Little Rooms: On the Phenomenology of Theatre. Stone J (2010) Harry Potter and the spectre of imprecision. Analysis; 70 (4): 639. Strawson P F (1950) On referring. Mind; 59 (235): 326.

Sullivan A (2005) Rigid designation, direct reference, and modal metaphysics. Pacific Philosophical Quarterly; 86: 577-599.

Thomasson A L (1999) Fiction and Metaphyisics. Cambridge. Cambridge University Press: pp 14-17.

Velleman J D (1997) How to Share an Intention. Philosophy and Phenomenological Research; 57 (1): 29-50.

Wittgenstein L (1969) Philosophical Investigations, 3rd edn. Trans. Anscombe G E M. Palgrave Macmillan Publishing: New York, \$293.

Woodruff P (2008) The Necessity of Theater. Oxford. Oxford University Press.

Zouhar M (2011) Are there directly referring non-rigid designators? Prolegomena; 10 (1): $87-100$

\section{Acknowledgements}

I wish to thank the following people who provided me with invaluable feedback, as this essay would never have been realized without their incisive comments: Marvin Carlson (The Graduate Center, CUNY); Jon Mackay (University of Wisconsin-Madison);
Robert Combs (The George Washington University); and Shai Cohen. Also, I wish to thank Ricci-Jane Adams, Robert Walton and Adva Weinstein (all three with the University of Melbourne) for their insightful comments and suggestions during our long, stimulating conversation after my presentation of an earlier version of this article, presented as a part of the Theatre Research Series at the University of Melbourne in April 2014. Finally, I wish to thank the anonymous reviewers for their detailed and con structive comments.

\section{Additional information}

Competing interests: The author declares no competing financial interests.

Reprints and permission information is available at http://www.palgrave-journals.com/ pal/authors/rights_and_permissions.html

How to cite this article: Michael Y Bennett (2015) Theatrical names and reference. Palgrave Communications 1:14005 doi: 10.1057/palcomms.2014.5.

(c) (i) This work is licensed under a Creative Commons Attribution 3.0 International License. The images or other third party material in this article are included in the article's Creative Commons license, unless indicated otherwise in the credit line; if the material is not included under the Creative Commons license, users will need to obtain permission from the license holder to reproduce the material. To view a copy of this license, visit http://creativecommons.org/licenses/by/3.0/ 